\title{
Developing Module of Guidance and Counseling Management Subject
}

\author{
Zuraida Lubis ${ }^{1 *}$, Sri Milfayetty ${ }^{2}$, Rahmulyani ${ }^{3}$, Nindya Ayu Pristanti ${ }^{4}$, \\ Utami Nurhafsari Putri ${ }^{5}$ \\ ${ }^{1-5)}$ Guidance and Counseling Department, Universitas Negeri Medan, Indonesia \\ *zur.loebis@gmail.com
}

\begin{abstract}
This study aimed to develope a standart module of Guidance and Counseling Management subject for semester II students of Guidance and Counseling, Faculty of Education, Medan State University. This type of research is research and development following the Borg and Gall models. Data collection techniques using a questionnaire given to content expert and media expert. Main field trial were given to 32 students and operational field trial were given 128 students with purposive sampling techniques. Data analysis techniques using quantitative descriptive analysis. The results showed that media expert give 67 score with the value is 83.75 in very good category. Meanwhile, Content expert give 90 score with the value is 90 in very good category. The main field trial obtained 2514 total score and the value is 78.56 in good category and the operational field trial stage obtained 12055 total score and the value is $94.17 \mathrm{n}$ very good category. In addition, the Effectiveness Test showed 92.19 value in very good category. Therefore, It can concluded that the Guidance and Counseling Management module is feasible to use.
\end{abstract}

Keywords: developing module, guidance and counseling management

\section{Introduction}

The higher education curriculum is a set of plans and arrangements regarding the content, study materials and study materials as well as how they are delivered, and the assessments used as guidelines for organizing learning activities in tertiary institutions. The curriculum must be designed based on relevance to the objectives, scope, and depth of the material, the organization that encourages the formation of hard skills and personality and behavioral skills (soft skills) that can be applied in various situations and conditions.

The Indonesian National Qualifications Framework curriculum is a curriculum that contains a competency qualification skeleton framework that can juxtapose, equalize, and integrate between the education and work training fields as well as work experience in the context of providing work competency recognition in accordance with the work structure in the various sectors. The IQF curriculum implemented at Medan State University forms the basis for faculties and study programs within the Medan State University to carry out work or apply knowledge and expertise.

Guidance and counseling study programs, especially in the guidance and counseling management course team, conduct analysis of teaching materials to improve the quality of learning in order to respond to the IQF curriculum which has parameters of work skills, scope of knowledge / knowledge, methods and level of ability in applying science / such knowledge as well as managerial abilities. 
Improving the quality of Guidance and Counselingmanagement courses is done by making teaching materials so that students can learn independently the materials and training of Guidance and Counselingmanagement and making student centered learning, teaching materials previously owned only mere theories from management books linked to Guidance and Counseling, so that materials are needed teaching that is able to combine theory and practice as well as problems related to field conditions so that the performance of graduates in the field is optimal in applying pedagogical competencies, especially material related to Guidance and Counseling managerial.

The Guidance and Counseling Management course team will develop a teaching material used in second semester students of Guidance and Counseling, Faculty of Education, Medan State University. This lesson material is in the form of modules which contain material for each meeting, exercise, summary and formative test designed to meet the needs of the field, because based on preliminary research conducted in March 2019 in several schools in Deli Serdang, Teacher guidance and counseling performance in terms of making the guidance and counseling department, using the results of the assessment, evaluating the program and applying the basics of guidance and counseling services are still in the low category.

As chairman and members of the guidance and counseling Management course team at the study program level felt responsible for preparing a standard of Guidance and Counseling Management Course Module for the Guidance and Counseling Department. The Guidance and Counseling Management Subject Team is determined to create teaching materials that are in accordance with the needs of the field so that learning outcomes are achieved and graduates have a good performance in conducting Guidance and Counseling management.

\section{Guidance and Counseling Management}

Management is the achievement of organizational goals in an effective and efficient way through planning the organization of leadership and controlling organizational resources, Daft [1] and Hilman [2] says that management is a function to achieve something through the activities of others and oversee individual efforts to achieve the same goals.

Management is needed in an organization including schools to develop strategic planning. The management function implemented in guidance and counseling can be realized in program planning, organizing activities, and all the supporting elements of Guidance and Counseling. Guidance and counseling is one component in the whole education system, especially in schools. Guidance and Counseling Teachers as one of the elements implementing education who have the responsibility of supporting the implementation of counseling services in schools, are required to have adequate insight into the basic concepts of guidance and counseling in schools including management of guidance and counseling.

Guidance and counseling are assistance services not teaching services, so the main focus is to provide direct services, both orientation services, information and group guidance, group counseling and other services. Guidance and counseling services are carried out through individual and group activities. Thus, the guidance and counseling teacher must understand how to create a guidance and counseling program so that all students get good service.

To achieve an effective and efficient Guidance and Counseling Department, there are several things that must be done, Irawan [3] namely: 1) Analysis of student needs; 2) Determination of guidance and counseling objectives; 3) Analysis of the school situation; 4) Determination of the type of activities to be carried out; 5) Determination of the method of implementing the activity; 6) Determination of personnel activities; 7) Preparation of facilities and activity costs; 8) Estimates about barriers to activities and ways to anticipate. 
Guidance and counseling will not be carried out systematically without organization, planning, clear goals and professional leadership. Organizing the guidance and counseling helps all school personnel, students and parents in optimizing their respective roles and preventing the misuse of the duties of each personnel. The duties and roles of each school personnel include;

1) The Principal, as the person in charge of all school activities, monitors and supervisors implementing Guidance and Counseling

2) Deputy Principal, assigned in accordance with their fields. His job is to implement the principal's policy, especially those related to Guidance and Counseling, information providers, to disseminate the Guidance and Counseling department in accordance with their fields.

3) The homeroom teacher, who serves as an information provider, monitors the progress and progress of students, facilitators in disseminating counseling services and helps identify students who need responsive services.

4) Subject Teachers, tasked with disseminating counseling services, providing information during the teaching and learning process, identifying and monitoring student progress.

5) Administrative Staff, tasked with helping to prepare and administer Guidance and Counseling activities as well as providing information about the implementation of Guidance and Counseling services

6) Guidance and Counseling teacher/ Counselor tasked with organizing Guidance and Counseling services, analyzing the characteristics and needs of students as well as school conditions, coordinating all Guidance and Counseling service personnel, compiling, implementing, evaluating programs, holding all Guidance and Counseling activities accountable to the school principal.

\section{Module Development}

Module is one form of teaching material that is packaged in a whole and systematic manner which includes a set of learning experiences as a learning tool that is independent so that students can learn independently [4]. This opinion is in line with the Ministry of National Education [5] which explains that the module is a set of teaching material that is presented systematically so that students can learn with or without the teacher. Furthermore Purwanto [6] argues that the module is a learning material that is designed systematically based on a particular curriculum and is packaged in the form of the smallest learning unit and allows learning independently in a certain time unit.

Based on the explanation above shows that the module is one of the media that can be used in the learning process that is packaged in the form of the smallest learning unit and allows it to be learned independently by students. The development of the Guidance and Counseling management module allows students to read independently and obtain information about Guidance and Counseling management without feeling awkward because it is done independently.

\section{Module Development Phase}

The module development has several stages of development starting from the planning stage, the writing stage, the trial review and revision stage, as well as the finalization and printing stages [6]. The steps for developing a module can be explained as follows: 1) The writing stage is the preparation of the module contents; 2 Writing stages, namely: Preparation for Outline / module design, Writing draft I, Completing draft I to draft II; 3) Testing and 
revision review stages, namely: expert review, small group trials, large group trials; 4) Finalization and printing stages, namely: making module manuscripts, printing.

The above opinion is used in the process of developing Guidance and Counseling management modules as a medium that can be used for Guidance and Counseling Lecturers in providing information about Guidance and Counseling management. It can be concluded that the module development process in this study starts from the preparation of the module contents outline, module design, trial and revision review through experts (material experts, service experts, and media experts), small group trials, large group trials, and finalization and printing.

\section{Development of Guidance and Counseling Management Subject}

Guidance and counseling management modules are compiled based on the Semester Learning Plan with some materials that are equipped with Formative Exercises and Exams, including basic concepts of management and organization, Management of guidance and counseling, Data Collection Management, Management of Information Services, Management of Placement and Distribution Services, Referal Management, Group Counseling Service Management, Consultancy Service Management, Designing a Comprehensive Guidance and Counseling Program, Individual Counseling Management and Assessment and Follow Up in Guidance and Counseling.

\section{Research Method}

The research conducted is a type of research and development (Research and Development or R\&D).

1) Steps in Development Research

Borg and Gall (1983) in Sugiyono [7] said that the model of the development has the following steps:

a. Need analysis

In the initial research phase, data collection was conducted through interviews with 10 representatives of students majoring in Guidance and Counseling second semester. Based on the interview results obtained information that there are no teaching materials in learning that are used as learning media. In addition, the results of the analysis of student needs conducted to 32 second semester students on the need to develop teaching materials showed a very high category.

b. Study of literature

At this stage, various literary studies began to be carried out by studying the relevant literature and in accordance with the variables of the research to be developed, namely literature relating to the management of guidance and counseling as a University course for all Guidance and Counseling students even semester (two) at Medan State University

2) The media developed in this research is the development of media in the form of modules. The module is one of the media that contains elements of images, text and independent tasks. This is intended to generate positive enthusiasm from students. Modules contain materials, exercises and formative assignments, also equipped with a glossary to make it easier to complete course assignments.

3) Initial product development that is making and compiling guidance and counseling management materials, then used as modules (draft 1) 
4) This trial was conducted to measure the feasibility of the module through the validation of material experts and media experts.

5) Revised preliminary field trials of module quality that have been tested on material experts, relevant media experts, and then revised as modules (draft II).

6) Main field trials, testing the modules in small groups of 32 student subjects using a sample selection technique that is purposive sampling.

7) Revision of main field trials, if there are unsatisfactory results of module contents or material that is not appropriate in the main field tests, the modules are revised again in accordance with the suggestions and criticisms of small groups (Draft III).

8) Operational field trials, testing modules in large groups of 128 students) test subjects.

9) The final product, based on the results of evaluations from operational field trials, has become a final product that is feasible to be implemented.

10) Product dissemination and implementation, disseminating the modules that have been made and disseminating and disseminating them, which can be done in collaboration with publishers to publish the products that have been made

The product development that will be carried out in this research reaches the tenth stage, which is the Dissemination and Implementation of the product, disseminating the modules that have been made and disseminating and disseminating them. The development procedures in this study can be presented in the form of pictures as follows:

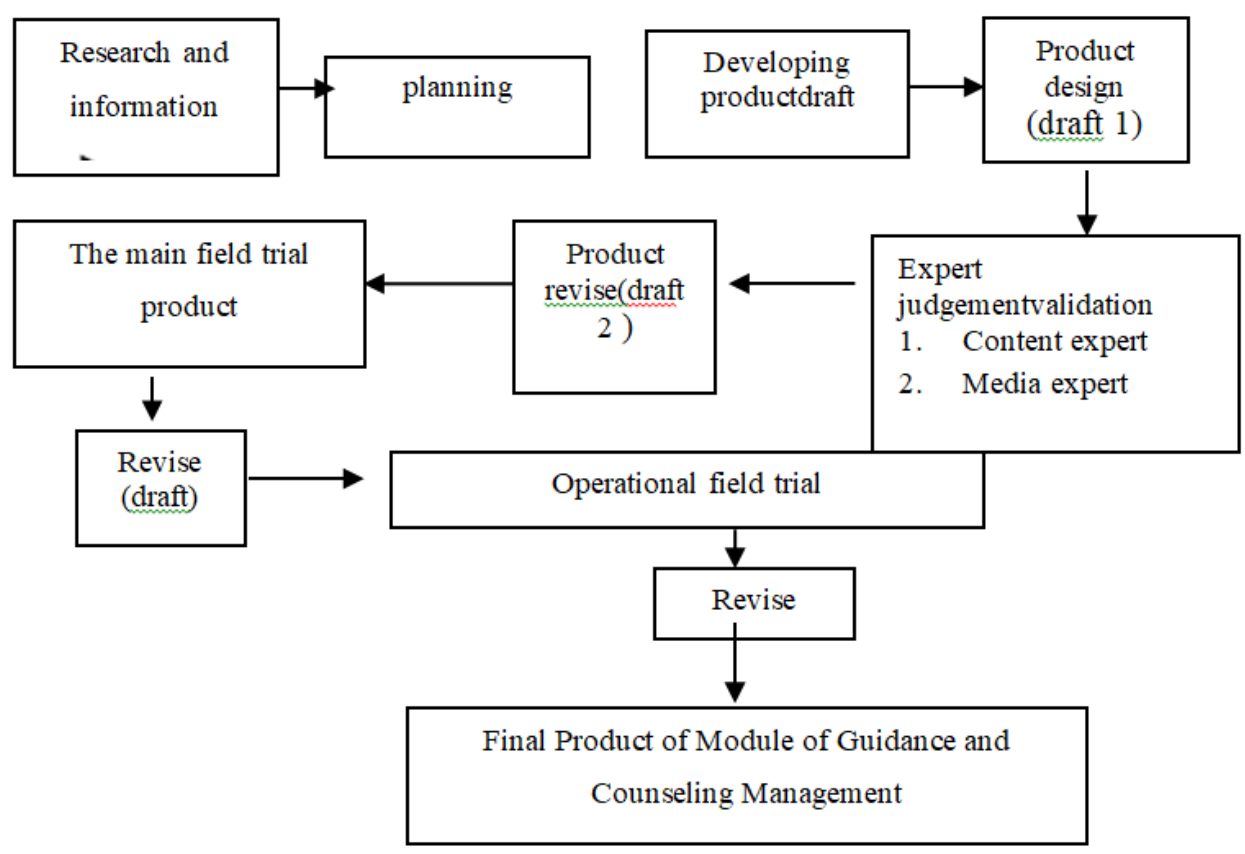

Figure 1. Development Research Steps

\section{Data Collection Techniques and Instruments}

Data collection techniques in this study used a questionnaire to assess the feasibility of the module through material experts and media experts [8]. Data collection techniques are the method chosen and used in research activities so that research can run systematically. Data 
collection in this study used questionnaire data collection or module eligibility questionnaires through expert validation and module effectiveness questionnaires given to students in limited product trials [9].

\section{Data analysis technique}

The data analysis technique used in this module development research is to use quantitative data analysis. Quantitative data analysis was obtained by descriptive quantitative analysis, namely analyzing quantitative data obtained from expert validation and limited field trials and trials of Suharsimi's operational field [11]. In this study a questionnaire was used with the following formula:

$$
\text { Value }=\frac{\text { Obtained Score }}{\text { Total score }} \times 100
$$

\section{Results and Discussion}

The development of Guidance and Counseling Management course modules for the second semester of Guidance and Counseling has been developed. The process of completing this module is carried out in stages in order to produce communicative learning media products that are suitable for use. The making of this module product has gone through a series of expert validations and field trials to users, besides expert validation and field trials are intended to obtain data as revision material.

The process of making this module has been revised gradually in accordance with the advice given by media experts, material experts, as well as data obtained from field trials at each stage. After the main field trials and operational field trials and data analysis at each stage of the trial it can be concluded that this module has become an Excellent final product to be used as a learning medium that can be used by guidance and counseling students.

The excellent results obtained by this service media are based on the results of the validation of media experts, material experts, as well as the process of main field trials and operational field trials. At the stage of validation of media experts obtained a total score of 67 so that the value of 83.75 with the category of Very Good, at the stage of validation of the material experts obtained a total score of 90 so that the value of 90 with the category of Very Good. At the main field trial stage, Based on the results of the questionnaire obtained a total score of 2514 so that the value of 78.56 with the Good category. At the operational field trial stage, the total score of 12055 is obtained so that the value of 94.17 is in the Very Good category.

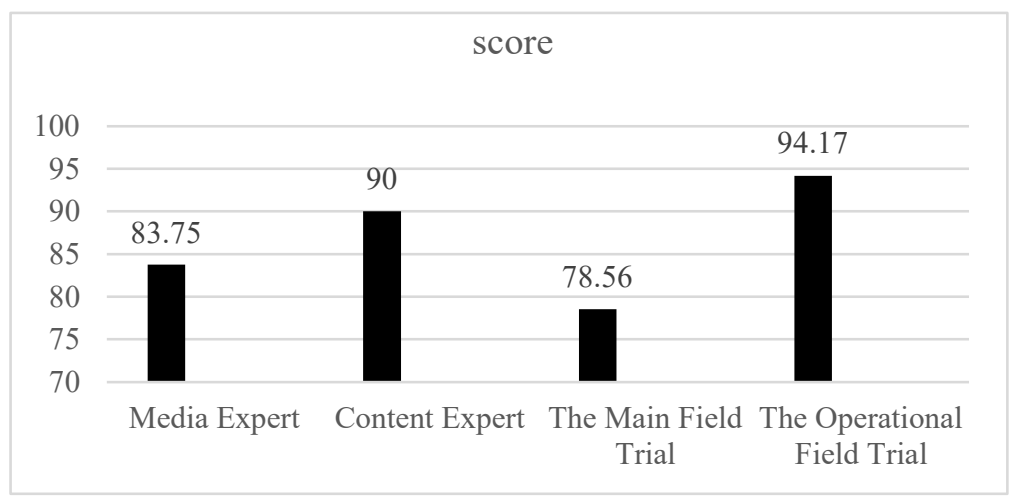

Figure 2. Score chart of expert test assessments and field trial 


\section{Level of Effectiveness of Guidance and Counseling Management Subjects Module}

The results of the level of effectiveness of students on the Guidance and Counseling Management course modules are conducted after an operational field test. The assessment was carried out using a questionnaire of the effectiveness of the Guidance and Counseling Management course class module which was held on August 26, 2019 at the Uniped Guidance and Counseling students with a total of 30 students. The results of the level of effectiveness of students on the Guidance and Counseling Management course modules obtained were 1217 so that the value of 92.19 with the category of Very Good [12].

\section{Conclusion}

The results of the research on the development of Guidance and Counseling Management modules for second semester guidance and counseling students are as follows:

1) Guidance and Counseling Management Course Module for students in the second semester of Guidance and Counseling is ready to be developed for students to use in the learning process.

2) This module contains cover, dean's remarks, preface from the Guidance and Counseling Management course team leader, general instructions, course descriptions, learning activities and reflections in each chapter.

3) Guidance and Counseling Management Course Module for students in the second semester of Guidance and Counseling is prepared based on the results of expert assessments that have been declared fit for use as learning media, and from the results of trials by users namely students, after going through initial field trials, main field trials, and operational field tests are included in the excellent category.

\section{References}

[1] Daft, Richard. (2002), Filsafat Administrasi, Jakarta: Gunung Agung.

[2] Hilman. (2010), Teori Organisasi dan Teknik Pengorganisasian. Bandung: Grafindo Persada.

[3] Irawan, Mirza. (2017), Implementasi Kurikulum Berbasis KKNI Pada Mata Kuliah Manajemen Bimbingan dan Konseling. Medan: Unimed.

[4] Daryanto. (2013), Menyusun Modul Bahan Ajar untuk Persiapan Guru dalam Mengajar. Yogyakarta : Gava Media.

15] Depdiknas. (2008), Panduan Pengembangan Bahan Ajar. Direktorat Pembinaan Sekolah Menengah Atas.

[6] Purwanto. (2007), Pengembangan Modul. Jakarta: Depdiknas.

[7[ Sugiyono. (2013), Metode Penelitian Pendidikan Pendekatan Kuantitatif, Kualitatif dan $R \& D$, Bandung: Alfabeta.

[8] Gall, M, D., Gall, J. P., \& Borg, W. R. (1983), Educational Research an Introduction; Third Edition. USA: Pearson Education.

[10] Republik Indonesia. (2014), Panduan Penyusunan Capaian Pembelajaran Lulusan Program Studi. Kementerian Pendidikan dan Kebudayaan.

[11] Suharsimi, (2019), Arikunto. Prosedur Penelitian. Jakarta: PT Rineka Cipta.

[12] Widodo, C. S., \& Jasmadi. (2008), Panduan Menyusun Bahan Ajar Berbasis Kompetensi. Jakarta: PT. Elex Media Komputindo. 